Russell West-Pavlov*

\title{
Shakespeare Among the Nyoongar: Post-Colonial Texts, Colonial Intertexts and their Imbrications - Macbeth in Gail Jones's Sorry
}

DOI 10.1515/zaa-2015-0033

\begin{abstract}
This article reads Gail Jones's 2007 novel Sorry as a novel of White usurpation of Indigenous country and culture. Sorry mobilizes a number of intertexts, primary among them Shakespeare. In particular Macbeth features prominently as a template for Sorry's drama of usurpation. My analysis focuses on two extensive quotations from Macbeth, recited by one of the novel's White protagonists as she surveys the scene of her husband's murder, ostensibly at the hands of an Indigenous servant, one of the 'Stolen Generations.' This recitation, however, proves itself to be an act of usurpation, as it is Perdita, the White child protagonist of the novel, who has stabbed her father during one of his repeated rapes of the Indigenous girl. Perdita, in turn, recovers her memory of the act via the recitation of the same passages from Macbeth, thus allowing Shakespeare to emerge in the White post-colonial text as a self-critical element of White usurping culture but also, possibly, as a collaborator in a coalition against the ongoing oppression of the Indigenous population which characterizes contemporary Australia.
\end{abstract}

\section{Cursed Usurpers}

A Nyoongar man stakes his claim to country:1 "“All roun heres,”, gestures Joey, an Indigenous character standing on the banks of the Swan River, "waving his arm across the river" (Jones 2007, 148). This part-verbal, part-gestural deixis in Australian author Gail Jones's 2007 novel Sorry supplements the text's own attribu-

1 'Nyoongar' is a regional term referring to the Indigenous peoples of South-Western Australia ('Murri' and 'Koori' refer to the peoples of North-Eastern and South-Eastern Australia respectively). For the article-less use of the word 'country' with its distinctive meaning within Indigenous Australian cosmologies and ecologies, see Rose 1996, 7.

*Corresponding author: Prof. Dr. Dr. Russell West-Pavlov, English Department, University of Tübingen, Wilhelmstr. 50, 72074 Tübingen, Germany; and English Department, University of Pretoria, Hatfield 0028, South Africa, e-mail: russell.west-pavlov@uni-tuebingen.de 
tion of semi-indirect, semi-FID speech: "They were Nyoongar people, Joey said; this was their country" (Jones 2007, 148). Yet who speaks here? The Indigenous character? - or the extradiegetic narrator, presumably White? (I say presumably White, because the extradiegetic voice appears to be a projection of the text's other narrator, an autodiegetic older version of the young girl Perdita addressed in the passage). When this extradiegetic narrator reports the Indigenous character's speech, are we not witness to a linguistic form of theft being perpetrated, one which is isomorphic (perhaps even identical [cf. Bonyhandy and Griffiths 2002]) with the White theft of Indigenous land? (“'White city,” Joey remarked wryly [Jones 2007, 147]). The aporia of speaking in place of an oppressed people at the moment of speaking on behalf of them (cf. Spivak 1999, 256-260), even in fiction, even when granting them a distinct 'voice' (indexed by the non-standard conventions of Aboriginal English), unavoidably entails a usurpation of Indigenous rights, yet another usurpation in a long history of usurpations.

Against this background of specifically literary encroachment upon territory and sovereignty, it is no coincidence, then, that the single most prominent intertext in Gail Jones's Sorry is not an Indigenous story, but a canonical English text about the arrogation of sovereignty, concluding with a public display of 'the usurper's cursed head' (Macbeth 5.9., 1. 21). ${ }^{2}$ Shakespeare does not merely portray usurpation; it may be that he also performs it. For he is an author whose preeminent role in crafting colonial culture around the globe is often seen as having a hand in the displacement of prior Indigenous narratives (cf. Orkin 1987; Loomba 1989; Distiller 2005; Schalkwyk 2012; Banham et al. 2013; Viswanathan 2015). For that reason, it is unsurprising that usurpation and its manifestations in the 'sickly weal' (Macbeth 5.2., 1. 27) - manifested in Indigenous Australia by the theft of sacred Indigenous land at a continental scale, the appropriation and destruction of the natural matrices of Indigenous culture, and the commodification and marketing of Indigenous 'authenticity' - are at the core of the novel's retooling of the Shakespearean intertext (Herrero 2011, 291). If, in the words of Deborah Bird Rose, "[s]ettler societies are brought into being through invasion: death and silence pervade and gird the whole project" (Rose 2004, 58), then in this text, the project of obfuscated White usurpation is refracted and reflected back to White settler society in the distorting mirror of one of its most cherished high-cultural icons.

In this article, I explore the resonances of Jones's various uses of Macbeth, arguing that Shakespeare's play about a usurper acts as a template for the portrayal of a White settler usurper (Perdita's father Nicholas), and his various accomplices (Perdita's mother Stella, and indeed, Perdita herself). More generally, however, I

2 All references in the article are to Shakespeare 1988. 
will suggest that Shakespeare himself figures as a usurper in Jones's novel, thus highlighting the aporia that probably beset all exemplars of settler culture on the continent, even the most contestatory.

Although I will mention a number of Jones's allusions to eight Shakespearean dramas (in order of appearance, The Winter's Tale, Hamlet, The Tempest, Macbeth, Othello, King Lear, Twelfth Night, Romeo and Juliet, and Richard II) and three sonnets $(50,19,60),{ }^{3}$ my argument will focus principally on two passages from Macbeth. In both, Stella, the protagonist's mother, recites passages from Macbeth at crucial junctures in the novel's action. I posit that the two passages are intimately linked: the first embodies the usurpations of Indigenous sovereignty and cultural primacy which contagiously taint all of settler society, while the second concerns the ways in which these historical processes may be perpetuated into the present, or conversely, rectified by some sort of redistributive justice. Finally, I will suggest that together they point up the limitations and possibilities of Shakespeare's texts in a post-colonial context - like Stella, usurping Indigenous culture in the wake of a usurping settler people, but in the infinite recontextualizations that the Shakespearean text is susceptible of, offering new, if limited, poetic and thus ethical possibilities of transformation.

\section{Shakespeare Among the Nyoongar}

What is Shakespeare doing here among the Nyoongar? ${ }^{4}$ He comes in the baggage of an English couple who move to the remote north of Western Australia, near Broome. The husband, Nicholas, is a second-rate anthropologist; his wife, Stella, cut loose from her family and culture moorings, is a social outcast who gradually loses her mind, her only anchor in an increasingly bleak environment "an early, inexplicable obsession with Shakespeare"; she has "committed to memory a small selection of plays and almost fifty sonnets" (Jones 2007, 7), which she recites at every opportunity.

Their daughter Perdita, christened after Shakespeare's heroine of The Winter's Tale (Jones 2007, 26), grows up in an outback nowhere, befriended by

3 The respective Shakespearean citations or allusions in Jones 2007: Hamlet 8, 28, 37, 38, 141, 161; King Lear 85, 100, 162; Macbeth 28, 51, 78, 89, 95, 124, 133, 191, 201, 202, 208, 209; Othello 77-80; Richard II 205, 207; Romeo and Juliet 140; The Tempest 12, 13, 199; Twelfth Night 138, 141; The Winter's Tale 3, 26, 63, 74; Sonnet 19 113; Sonnet 50 16; Sonnet 60 174, 179, 182.

4 Strictly speaking, Shakespeare engages with the Nyoongar people in the second half of the novel, centered in Perth; the customary cross-regional terms do not cover the North-West. 
her ersatz sister Mary, an Indigenous girl who has been "seized [...] from her mother" (Jones 2007, 55) and taken first to a mission, then to an orphanage, before coming to the family as a domestic servant. Mary is one of the so-called 'Stolen Generations,' the between 50- to 100,000 mixed-background Indigenous children removed from their families by the government all down the twentieth century in a concerted campaign to breed racial hybridity out of existence. Jones's novel resonates strongly, for instance, with Kim Scott's 1999 novel Benang, Doris Pilkington/Nugi Garimara's Follow the Rabbit Proof Fence of 1996, adapted as a successful film in 2002 (screened in Europe as Long Walk Home), and the government-commissioned report on the separation of Indigenous children from their families published in 1997 as Bringing Them Home (cf. HREOC 1997). Mary exemplifies the fate of thousands of children of White fathers and Indigenous mothers, removed and then farmed out to work as rural labourers or domestic help, and often subjected to mistreatment and sexual abuse (cf. Haebich 2000; Haebich and Mellor 2002). Mary is repeatedly assaulted by Nicholas until one day he is murdered during the act of rape. Mary is incarcerated for the murder, Stella subsides further into insanity, and Perdita acquires a stutter that reduces her to virtual mutism. It is only when a therapy based on recitation of Shakespearean sonnets restores Perdita's speech that she also regains her memory of what, it transpires, was in fact her act of patricide. But Perdita's linguistic and mnemonic healing comes too late for Mary. Perdita fails to offer an apology for the suffering her Indigenous 'sister' has incurred on her behalf, Stella refuses to testify to prove Mary's innocence, and Mary dies in prison.

This brief summary of Jones's plot serves to situate her versions of Shakespeare and their multiple, even contradictory functions within the post-colonial text. One of Jones's Macbeth epigraphs summarizes the situation:

Foul whisperings are abroad. Unnatural deeds

Do breed unnatural troubles; infected minds

To their deaf pillows will discharge their secrets. (Jones 2007, 51; Macbeth 5.1., 11. 68-70)

The quotation from Macbeth refers obliquely to the 'unnatural deeds' perpetrated by Nicholas and other White males who would subsequently disavow paternity, in complicity with the state's usurpation of Indigenous maternal custody; more broadly, it refers to the disturbed macrocosm of an usurped Indigenous cosmos destroyed by White invasion (Swain 1993); the 'infected mind' is that of Stella, but more generally of a White settler mentality with its cultural and educational institutions, within which Shakespeare has always been a central pillar. Thus, the Shakespearean intertext possesses multiple valencies within Jones's novel. At a fairly straightforward level, it constitutes a memorized body of texts which offers 
Stella some sort of anchor as she slides into madness. To Perdita, taught at home by her crazed mother, Shakespeare gives a framing knowledge of the world which, it turns out, is dangerously limited, though not entirely devoid of redemptive power. On a figurative level, Shakespeare furnishes an ironic commentary upon the Whiteman's usurpation of the Indigenous world, introduced as part of that usurpation but capable of interrogating it, always ambivalently both critique of and symptomatic part of the 'sickly weal' (Macbeth 5.2., 1. 27) of White Australia.

Sorry is thus part of an emerging post-colonial canon which interrogates the place of the metropolitan classics in a not-yet-entirely post-colonial polity such as contemporary Australia; Shakespeare functions in the novel not only as a complicit and contestatory text, but also as a synecdoche for critical White culture on a usurped continent. Shakespeare thus exemplifies the uneasy interaction between White settler culture, even in its politically leftliberal manifestations, and the ongoing situation of (still-)colonized peoples (cf. Spivak 1993).

The convoluted ambivalences of the post-colonial Shakespearean text can be illustrated via two direct quotations from Macbeth that are central to the action of Sorry. The first is the passage where Lady Macbeth, in Act 2, Scene 2 of Shakespeare's drama, castigates her husband for his faltering resolve, demands the daggers, and proposes to bloody the dead king's grooms so as to suggest their guilt:

\author{
Infirm of purpose! \\ Give me the daggers: the sleeping and the dead \\ Are as but pictures: 'tis the eye of childhood \\ That fears a painted devil. If he do bleed, \\ I'll gilt the faces of the grooms withal \\ For it must seem their guilt. (Macbeth 2.2., 11. 50-55)
}

The passage is rendered twice in the novel, in two of the three separate narrations of Nicholas's death (Jones 2007, 124; 191), spoken by Stella who abruptly appears in the corner of the shack just after her husband has been stabbed. The second Shakespearean quotation I will discuss is much shorter, and consists of Stella's reiterated response, when asked to testify to Perdita's crime so as to absolve Mary of guilt, 'What is done cannot be undone' (Macbeth 5.1., 1. 65).

In what follows, I will suggest that the two passages are intimately linked: the first passage embodies the usurpations of Indigenous sovereignty and cultural primacy which contagiously taint all of settler society; the second concerns the ways in which these historical processes may be perpetuated into the present, or conversely, rectified by some sort of redistributive justice. 


\section{Stella's Daggers}

Immediately after Nicholas's death, Mary confesses to the crime, her Lady-Macbeth-like gesture of trying to rub off the "foul taint of all that has happened" (Jones 2007, 194), apparently confirming her guilt. However, it subsequently transpires that these are merely 'taints and blames I laid upon myself' (Malcolm's words in Macbeth 4.3., 1. 125) to protect Perdita from punishment (Jones 2007, 195; 203). However, it is Perdita's mother who recites Lady Macbeth's verses about the dagger (Jones 2007, 191; 194), leading us, and several characters in the book, to believe that she is the murderer of the sadistic and unfaithful husband who has driven her to madness (Jones 2007, 165; 190; 195). But in fact, her mimicked demand, 'Give me the daggers' (Jones 2007, 191) as she gazes down at the bloodied body of her husband, enacts in its appropriative force, her "gloating" usurpation (Jones 2007, 194) of a role which is, in reality, her daughter's.

Stella usurps the role of tyrannocide by declaiming Macbeth on the margins of the murder, thereby allowing her daughter, who is struck with post-traumatic amnesia and aphasia, to believe that she is the conjugal perpetrator. The mendacity of her role is underlined, of course, by the fact that the victim in the original play, Duncan, is not a tyrant; this is one of several significant mismatches between Stella's assumed role and its Shakespearean template. Stella's quoting of the words 'I'll gilt the faces of the grooms withal/For it must seem their guilt' (Macbeth 2.2., 11.54-55) ironically reverses the performative force of her utterance, for it is her own being that she 'gilts' with a seeming 'guilt' (conversely, however, her later refusal to absolve Mary will maintain the latter's willingly-assumed but fictive guilt, thereby confirming the import of the citation). Stella thus takes up stance of spurious revolt; like Lady Macbeth in Coleridge's reading of the play, she "mistakes the courage of fantasy for the power of bearing the consequences of the realities of guilt" (Coleridge 1960, I, 64). Stella takes the credit for a revenge committed by a proxy. This appropriation, moreover, is to her own advantage rather than in aid of the other mistreated woman of the scene. This local usurpation elides the other fictional women's suffering, and as element in a White family drama, it also elides the collective trauma of the Black Indigenous people. Stella's usurpation thus obfuscates a larger drama of usurpation which up until the $1960 \mathrm{~s}$ was largely unknown within the White Australian public sphere.

More specifically then, the passage's reference to childhood, one of the central thematic strands of the play (Brooks 1947, 49), elides the real drama being carried out in the shack: the removal and abuse of Indigenous children designed to bring about, over generations, their demographic disappearance. Stella's quotation thus helps to keep 'the eye of childhood' (Macbeth 2.2., 1. 54) well out of the public eye. To recite this passage from Shakespeare at this epoch in this particular situation is 
to perform (in all the literal force of the word) complicity with a generalized White usurpation of Indigenous time and space. Such complicity is confirmed and reinforced by the second Shakespearean allusion I will discuss below, Stella's 'What is done cannot be undone,' which again ventriloquizes Lady Macbeth in Act 5, Scene 1 , resists redress, and insists upon the impossibility of change.

In the final, recalled version of the murder scene, Perdita recites for her therapist the lines that Stella recited over Nicholas's body. In this passage, Jones adds to those lines already cited, Macbeth's lines: 'Is this a dagger which I see before me,/ The handle towards my hand? Come, let me clutch thee' (Jones 2007, 192; Macbeth 2.1., 11.34-35). At the moment of recovery of memory, the preceding theft of memory, and with it, the erasure of responsibility, is laid bare. This laying bare, however, only occurs through Perdita's re-appropriation of Macbeth's lines from the usurping outback Lady Macbeth, her mother Stella. For only now is Perdita's act, under the erasure of post-traumatic amnesia until these last pages of the novel, finally revealed, triggered by the reading of Shakespeare in the crucial stuttering therapy session. Perdita's 'Come, let me clutch thee' thus refers not only to the dagger which, via the restoration of memory, she once again take up as her own, thus re-assuming a responsibility she had ascribed to another, but also to the Shakespearean lines themselves, which she seizes back from their original usurper. The (daughter's) reusurpation of a (mother's) usurpation of a (father's) usurpation of (White settler) usurpation allows the erased past suddenly to come to light again. Shakespeare's drama of usurpation, transported as a (cultural) foreign body to the great southern land, nevertheless provides a "flaunted language," a “rude excess" (Jones 2007, 7) which allows it to disturb this local manifestation of what W. H. Stanner famously called the "great silence" reigning over Australian colonial (and post-independence) history (Stanner 1969, 25). Invoking Shakespeare as a high-cultural operator distant and alien enough to facilitate the defamiliarization of habitual majority consciousness begs the question, however, of the multiple instances of overlaid and embedded usurpations which constitute Australian geopolitical history. How much can high-cultural literary texts (Shakespeare as mobilized by Jones's novel) really help in undoing the past? When one considers 'How long a time lies in one little word' (Jones 2007, 205; Richard II 1.3., 1. 206), is Sorry with its manifold Shakespearean words enough to heal more than two centuries of usurpation?

\section{What's Done Cannot Be Undone}

Stella's twice-enunciated “'What's done cannot be undone”" (Jones 2007, 201; 202) repeats Lady Macbeth's 'what's done is done' (Macbeth 3.1.) and its negative 
'what's done cannot be undone' (Macbeth 5.1., 1. 65). By doubling the negative, Jones seems to want to outdo here Lady Macbeth's duplicitous words, 'In every point twice done and then done double' (Macbeth 1.6., 1. 15); she thereby ostends, however, a prominent temporal structure of repetition/perpetuation within the novel and within an Indigenous history of loss in general.

With this quotation, Stella refuses to cede her usurped responsibility back to Perdita so as to release Mary from guilt. In Shakespeare's drama, Lady Macbeth's statement reveals precisely its opposite, namely, the self-undoing trajectory of the process of usurpation (Eagleton 1967, 130). Earlier, Macbeth has meditated on an 'even-handed Justice,' somewhat akin to Hooker's natural law (Tillyard [1943] 1978, 22-24; Kirby 1999), which dictates that 'Bloody instructions, which, being taught, return/To plague th'inventor' (Macbeth 1.7., 11. 8-10). Lady Macbeth's fatalistic attitude, which is radically contrary to the Christian ethic of forgiveness and redemption, paradoxically, almost anachronistically segues into a modern conviction of the irreversibility of history (West-Pavlov 2013, 33-38). Such a notion of linear temporality is insidiously related to the belief in progress that underpinned the dying race theory (Brantlinger 1995) and drove the eugenic policy of child removal which was supposed to assimilate (and thereby eradicate) the so-called 'half-caste population': "The Aborigine [...] like all primitive peoples, had a tendency to expire on contact with a superior race. It was the sad duty of Civilized Man to raise or erase the lesser humans, to enable the March of Progress and the Completion of God's Plan” (Jones 2007, 12). Here, modernity's linear time becomes complicit with a time of "necropolitics," to use Mbembe's (2003) postcolonial retooling of Agamben's (1998) influential notion of biopolitics.

Stella's repeated refusal to offer absolution to Mary (Jones 2007, 201; 202) reveals that she, like Nicholas, subscribes to the notion of a historically determined demise of the Indigenous people that she does not deign to tamper with. Her refusal to do anything to hinder Mary's incarceration culminates in the girl's death, which an official missive deems (perhaps over-emphatically) not to be the result of malpractice (Jones 2007, 210). These hints make Mary's end an early precursor of the thousands of so-called 'Aboriginal deaths in custody' investigated by another commission of enquiry, whose report of 1991 also largely exculpated police and prison officials (Royal Commission into Aboriginal Deaths in Custody 1991; cf. ATSIC 1996).

'What's done cannot be undone' is Lady Macbeth's riposte to the tragic plot in which she finds herself embroiled, in which evil within the body politic can and will be undone by the "purging" of the malady. The tragic plot constitutes the reversal of evil by a radical and brutal cure for the 'sickly weal': 'our country's purge' in the form of English military 'med'cine' (Macbeth 5.2., 11. 27-29). Lady Macbeth, then, is wrong: what's done can be undone. Balance will be restored in 
the body politic, with the help of England, a nod at James's own policy on Scotland and his efforts for 'universal peace' and 'unity on earth' (Macbeth 4.3., 1. 99; 1. 100).

In Sorry, however, there is no such redemptive undoing, but rather, an ongoing "politics of stolen time" (Frow 2011) that entails "something irrecoverable" and a tragic and irreparable discovery of "the limits of possibility" (Jones 2004, 165). The fact that Perdita fails to say sorry, except in a very indirect manner cast in a form of interior monologue (Jones 2007, 204; 211), implies that history cannot be resolved or suffering healed or brought to redemptive closure within fiction. For, when as the Bringing Them Home report had recommended (HREOC 1997, 651), a governmental apology came, shortly after the completion of Jones's novel in 2007 (Rudd 2008), it was a pretty sorry apology - one that offered penitence for the up-to-100,000 child removals, but failed to address the deeper seated issues of genocide (Barta 2008) or sovereignty (Reynolds 1996). It was, in Coetzee's caustic formulation at the time, exemplary of a trend "to word apologies without admitting liability” (Coetzee 2007, 108). Significantly, Jones's invocation of 'How long a time lies in one little word' (Jones 2007, 205; Richard II 1.3., 1. 206), which comments obliquely on the withholding (at the moment of the text's composition) of an official apology, contains a hidden snag. Bolingbroke acknowledges with these words not an apology but a reinstatement after a period of banishment, a 'welcome home' (Richard II 1.3., 1. 205) that is a restoration of geographical belonging and a restitution of jurisdiction - one that the Australian government's 'sorry' was at pains to avoid.

Even more ironically, the 2008 apology came in the midst of the newlylaunched Northern Territory Emergency Response, or "NT Intervention," implemented in the name of child protection measures, which suspended civic rights and racial discrimination legislation, implemented rigid measures of social control, and rescinded land rights for a significant number of Indigenous communities in NT (Gray 2011a,b). The state of emergency was extended until 2012 by successive commonwealth governments (under the leadership of Rudd and Gillard), and then replaced, in a doubtless unintended gesture of irony, by the current 'Stronger Futures Policy,' for a further ten years. Colonial governance lives on ... and on. A paranoid reading of the jovial title of the 'Stronger Futures' policy and its ten-year span would detect a sinister subtext about the tendency towards self-perpetuation embedded in the very notion of martial law or of the state of emergency. As Doris Pilkington/Nugi Garimara writes of her kin in the 1930s, using a significant play of tenses, “They were grieving for their abducted children and their relief would come only when the tears ceased to fall, and that will be a long time yet” (Pilkington/Garimara 1996, 45). The inflection of such statements confirms Agamben's suspicion that the state of emergency, today, tends to extend itself indefinitely (Agamben 2005, 86-87; 168-169). 
Against this impossibility of redemptive closure, evinced also in Jones's novel, an equal and opposite tendency for Shakespeare's text to reassert its relevance, however in the most diverse historical and geographical contexts, is manifest here (Taylor 1991). Shakespeare resurges, however, in an unruly way that more often than not goes against the grain of attempts to assert his universality and his timelessness. Such unruliness is evinced by Macbeth's opaque and aporetic 'tomorrow and tomorrow and tomorrow' (Jones 2007, 209; Macbeth 5.5., 1. 18) which balances ambiguously between sequence and repetition, between futurity and statis. Macbeth's enigmatic utterance may exemplify what Jones, in a piece published several years before the novel, has named "deconstructive time" (Jones 2004, 159). Macbeth's utterance appears to echo the sequential drive of linear, teleological time, resisting reversal, declaring the ultimate demise of disposable ethnicities and racialized populations; but its insistent, indeed manic repetition may also simultaneously index the unclosed time-of-emergency still terrifyingly concrete in White Australia's contemporary colonial regime. Such a temporality eludes the binarized before and after, not-yet-done and already-done of sequential temporality, only to tip it over into the nightmare eternity of the latemodern state of emergency.

Far from battening down history under the blanket of timelessness, thus, at each turn Shakespeare opens it up, suggesting new and unsettling resonances, "blasting a specific era out of the homogeneous course of history," in Benjamin's famous formulation, re-envisaging "the past [...] seized [...] as an image which flashes up [...] in a moment of danger” (Benjamin 1999, 254; 247). This unpredictable wont of Shakespeare's creative work to resonate with times other than his own means that again and again, his oeuvre "suddenly stops in a configuration pregnant with tensions, it gives that configuration a shock," and "grasps the constellation which his own era has formed with a definite [later] one" (Benjamin 1999, 254; 255, my modification). Such temporal configurations of Shakespeare's relevance are also synchronic confrontations fraught with power struggles: they reveal, in Jones's comments upon her novel, "a hinge mechanism in the book that talks about the problems with a governing culture taking over linguistically but also uses that as a redemptive space [...] there are spaces of both authority and dissent in every language” (Jones in a 2007 interview with Rob Cawston, qtd. in Kossew 2013, 179). Such moments of Bakhtinian ambivalence or hybridity in the literary word or the canonical text (Bakhtin 1981, 358-362), which in turn reveal the multiple valencies of superimposed historical epochs, I will suggest in what follows, have however little to do with Shakespeare's universal genius and everything to do with his unexpected, anachronistic 'kinship' with Indigenous modes of thought. 


\section{Shakespeare: "Encompasser of Every Human Range?"}

Macbeth's initial reluctance to kill Duncan stems, amongst other things, from his awareness that he is about to usurp not only kingship but also kinship: 'I am his kinsman and his subject,/Strong both against the deed' (Macbeth 1.7., 11. 12-14). Early modern theories of monarchy believed the king's physical person to be somehow coeval with the body politic as a whole (Kantorowicz 1957), a relationship which is overlaid here with familial-dynastic kinship bonds. The micromacrocosmic notions of the early modern universe extended this kinship, in one form or another, albeit in an absolutely hierarchical manner, to the entirety of the body politic (Foucault 2002, 19-50; Lovejoy 1957). (The canonical, if not entirely unironic expression of this worldview [Kiernan 1996, 134] is contained in Ulysses' speech on 'degree' in Troilus and Cressida 1.3., 11. 85-124; a more openly satirical version of the same is presented in Coriolanus 1.1., 11. 94-161.) In Macbeth, this natural order of things is manifested mostly in negative form in the image of a wounded body politic suffering under Macbeth's tyrannical reign:

Bleed, bleed, poor country! [...]

I think our country sinks beneath the yoke;

It weeps, it bleeds; and each day a new gash

Is added to her wounds. (Macbeth 4.3., 1. 31; 11. 39-41)

Such notions resonate strongly with Indigenous descriptions of "sick" country (Rose 1996, 66; cf. also Rose 2004, 34-62), against which Sorry poses an Indigenous universe of "vast, imperishable life [...] everywhere apparent" (Jones 2007, 60). Other Indigenous texts from the same part of Australia make this cosmic order an extended cross-species realm of kinship: thus, the protagonist of Doris Pilkington/Nugi Garimara's Follow the Rabbit-Proof Fence, Molly, "had no fear" during the escape from detention in the Moore River Native Settlement "because the wilderness was her kin. It always provided food, shelter and sustenance. She had learnt and developed bushcraft skills and survival techniques from an expert, her stepfather, a former nomad from the desert” (Pilkington/Garimara 1996, 82).

It is here that Shakespeare appears as an early-modern European exemplar of a defence of cosmic kinship against the disruptive force of usurpation. This agonistic struggle maps almost exactly onto Sorry's opposition of Indigenous kinship against White settler usurpation, a project in which Nicholas is intimately involved. As an anthropologist he provides "knowledge of how the Black buggers thought [that] would be useful in their management and control" (Jones 2007, 12); his "research hypothesis" posits that 
kin would have to be destroyed if Aborigines were to enter the modern world. [...] It made them think in communal, not individual terms, so that they were always bound to the past, to tribal savagery, not looking forward to the new self that would equip them for twentiethcentury Australia. (Jones 2007, 71)

In line with his anti-kin theories, Nicholas's repeated rapes of Mary are thus part of a pattern of violent sexuality that perpetuates the 'Stolen Generations' trauma. His sexual predation disrupts kinship by anticipating on the policy of assimilation, which would breed successive generations of ever-paler mixed-background children until "[t]he Black will go White," until "the colour [...] is lost" (Daily News, 3 October 1933, qtd. in Scott 1999, 5).

In contrast to Nicholas's sexualized declaration of war on kinship, which seeks to isolate the individual Indigenous subject and thus eliminate the Indigenous collectivity, Perdita discovers that she has been "given a skin group," which makes her a daughter of the elder Mandjabari and Mary's sister:

[...] in their generosity, the creek people had bestowed on Perdita a relationship of skin. [...] A kind of family without limits.

Perdita [...] knew herself suddenly to be implicated in a wider pattern, where there would always be someone, somewhere, to know of and look after her; [...]. (Jones 2007, 73; 72)

Against the template of Shakespeare's usurped natural order, Jones is able to suggest a cosmic struggle between coherence and disruption, between Black and White Australia (cf. for instance Rowse 1993). Perdita and Stella, as adversarial custodians of Shakespeare, are ranged on opposing sides in this cosmic clash between a limitless, interrelated natural order and a history of acts of usurpation.

But is not Shakespeare himself a usurper in this scenario? What of his status as the supreme literary exemplar of "a governing culture taking over linguistically" (Jones in a 2007 interview with Rob Cawston, qtd. in Kossew 2013, 179), and of "the irreversible triumph of the language that had usurped all others in which people once discussed their differences" (Ghosh 1994, 236)?

In one central showdown between mother and daughter, Stella, referring to Hamlet's 'O, that this too solid flesh would melt' speech (Jones 2007, 37; Hamlet 1.2., 11.129-137), asserts the universal genius of Shakespeare: "Stella declared that this speech, and others like it, were about 'the big questions.' She told her daughter that everything one needed to know about life was contained in a volume of Shakespeare; that he was all-wise, incomparable, the encompasser of every human range" (Jones 2007, 37). Jones immediately refutes this claim, posing against Hamlet's desire for fleshly life to melt away a persistent dynamic of material life as the vital fabric of Indigenous belief: 
Even as a child, Perdita knew this to be false. She stepped out into the dazzling light of Australia; [...] she felt hot wind brush her face and heard the hum of the blowflies and the crackle of live things dessicating and the scamper of unseen lizards; all this life, all this huge, unelaborated life, told her there was more on heaven and earth than was dreamt of by Mister Shakespeare.

There were the dreaming spaces that Mandjabari knew of, and old man Dauwarrngu. There were $[\ldots]$ all the unremarked, simple and non-noble feelings, the taste of warm water dribbling from a canvas bag, the silky air of early evening shining with nickel-glow, the floaty feeling induced by hearing Aboriginal songs by firelight, and the rhythm of the clap sticks, repeating, and the words, the Language, drifting and braiding, drifting and braiding and dissolving into the darkness, like wind, like forgetting. Small questions, Perdita thought. There were small questions here. Or perhaps - the idea subversively filled her head - there were different big questions. (Jones 2007, 37-38, emphasis in the original)

Stella remains adamant: "When [Perdita] tried to discuss this with her mother, she was met with staunch refutation. Stella [...] said that some things in life were implicitly understood: [...] the peerless, exceptional genius of Shakespeare. [...] Shakespeare had identified, she asserted again, all the 'big' questions" (Jones 2007,38 , emphasis in the original). Ironically, the dismantling of Shakespeare which takes place in this passage, despite Stella's temporary re-assertion of canonical authority, is launched by Shakespeare himself, via an unmistakeable allusion to Hamlet, 'There are more things in heaven and earth, Horatio,/Than are dreamt of in your philosophy' (Hamlet 1.5., 11. 167-168). The reference to 'more things' is performatively embedded within and surrounded by "all this huge, unelaborated life" of the Indigenous world in its capacious inclusion of all things and all forms of existence, extending to "the dreaming spaces" beyond the ken of European knowledge (Jones 2007, 38). Does Shakespeare perhaps also share the same "skin group" as Indigenous culture? By making him 'do' kinship as well as Indigenous lore, does the text have him surreptitiously usurp that culture? Is this "a trespass, or a reclamation?" (Jones 2007, 192)

Elsewhere the same iconoclastic (but secretly reverential, and perhaps Whiteusurpatory) gesture is repeated. The text quotes the opening lines of Sonnet 60 on three successive occasions:

Like as the waves make towards the pebbled shore,

So do our minutes hasten to their end;

Each changing place with that which goes before,

In sequent toll all forwards to contend. (Jones 2007, 174; 179; 182; Sonnet 60, 758)

The novel returns again and again to this sonnet only, however, to refute its claim all the more vociferously: 
Then, all of a sudden, I realized Shakespeare was wrong. There was no forward incessancy, like waves meeting waves, but recursion, fold, things revisiting out of time. [...] my sense too was of the implicating dragnet of the past, the accumulated experiences to which I was somehow compelled to return, the again and again, one might say, of moments drastically mistaken. [...] these summonings were a form of backwards learning. I recognized my haltings and erasures, my bothersome blanks. (Jones 2007, 182)

Jones's refutation of a linear theory of time serves to buttress a psychoanalytic theory of temporality, one in which the past is constantly re-worked by the present in a process which Freud famously termed "deferred action" or "secondary revision" ('Nachträglichkeit'). Jones's description of what is effectively a Freudian and post-Freudian notion of time comes shortly before the episode in which Perdita, reciting precisely that verse from Macbeth that her mother had recited over Nicholas's bleeding corpse, abruptly remembers her own repressed action of patricide (Jones 2007, 192-197). Shakespeare, so it seems, has his uses after all, even in this backwater of the Antipodean post-colony. Sometimes, somehow, though he may be wrong, he can do right.

More interestingly, however, Jones's vocabulary provides glimpses of another reason why Shakespeare may be out of his depth in outback Australia. The notion of "recursion, fold, things revisiting out of time" discretely evoke the massive, enduring time of Indigenous mythology embedded in the land itself, in which the ancestral/dreaming "past does not so much precede the present, as lie contained within it" (Rickard 1996, 4). The relentless, forward-moving waves that Jones rejects in favor of recursive time have echoes of more than merely a Freudian "deconstructive" time of repression, secondary revision or trauma (Jones 2004, 159), or of the "pleats of the self" (Jones 2007, 213). More radically, these topoi of folding (cf. Deleuze 1988) also resonate with the "ripples" (Jones 2007, 54; 212) that are the signatures of an immense, ongoing interfolding of all things: "all that had been inscribed there before them, in a hidden language never noticed became suddenly visible" (Jones 2007, 54). Shakespeare is merely one of the inscriptions gathered up in the "pleats" of a macro-self, the natural world as an infinitely differentiated and dynamic continuum.

Jones asserts thus a certain iconoclastic dethroning of Shakespeare. Nonetheless, her text, manifestly replete with Shakespearean allusions to the extent that it is, appears to perform in quite concrete ways precisely the opposite. There are more than a dozen quotations or allusions to Macbeth, and at least a score to other plays or sonnets. Possessed of a residual oral literary status, indubitably endowed with an incantatory power, Stella's and Perdita's Shakespeares compete with and displace the stories of the Indigenous people, "the speaking land," in the Berndts' evocative title (Berndt and Berndt 1989), or in Jones's phrase, "all that was told when they were on a walkabout [...] the bush knowledge, and the 
shared stories of mothers" (Jones 2007, 65). In Jones's otherwise post-colonialist text, "interested" as it undeniably is "in what is forgotten, the way certain voices in history are forgotten, [...] the rights and values of Indigenous people are lost or locked away" (Jones, interview with Rob Cawston, qtd. in Kossew 2013, 173), there is little mention of such traditions, let alone a voice for them, except for a passing allusion to "a woman spirit in the town, a woman in a red dress, who appeared and disappeared, without reason or warning” (Jones 2007, 107-108). Jones does not linger on this brief allusion. However, because this is part of the macaronic knowledge about Broome passed on to Perdita by Mary, we, perhaps, should linger a moment over this passage.

An equally laconic note in the acknowledgements (Jones 2007, 218) reveals that Broome spirit-woman is a figure from a Yawuru story to be found in an anthology entitled Those Who Remain Will Always Remember (Brewster et al. 2000). A closer reading of this story shows that Jones does not neglect Indigenous narrative as completely as it might appear at first glance, but simply indexes it in a highly elliptical fashion. The story of the spirit-woman turns out to contain within its brief span, via the witnesses' various interpretations of the so-called 'Red-Dress Woman,' something like a condensed compendium of Indigenous history. The Red-Dress Woman is thought to be "a woman who had been killed in the time of early contact with the White people"; she is also rumoured to be one of the countless Indigenous mothers of the Stolen Generations: "It was also said that her children were taken away from her." Finally, however, it transpires that she is associated with "places where there still remain very old indigenous trees in the traditional camping or ceremonial places in the town of Broome"; moreover, the Red-Dress Woman is believed to be "linked to women's business and must be treated with respect if encountered” (Mamajun Torres 2000, 19-20). The concluding indices of sacred geography and traditional custom cap and override, or perhaps better envelope or pervade, like an "abiding event" (Swain 1993), the two preceding instances of colonial and post-colonial depredation of Indigenous culture. In indexical form, Jones's elliptical allusion thus does something comparable to Paddy Roe's stories as transcribed by Stephen Muecke in Gularabulu (Roe 1983) and Reading the Country (Benterrak et al. 1984) (to take only one example of several possible alternatives; Roe is a storyteller from the Broome area, which makes his tales particularly cognate with Jones's narrative). Is Jones perhaps seeking, in this way, not to usurp Indigenous stories to the extent that she does not annex them for her own text? Is this possibly a deliberately staged literary, intertextual equivalent of Vattimo's “weak thought” (Vattimo 1980, 9-10), pointing to Indigenous narrative traditions but refusing to coopt them for her own narrative?

Perhaps this is why Sorry restricts itself to evocations of the quality of the "fragments of their language, Yawan" that Perdita learns from the Indigenous 
nursemaids; as a child, Perdita says, "I loved the full-mouthed sounds of indigenous nouns, the clever and precise onomatopoeia of the bird names, the cyclical songs, full of sonorous droning" (Jones 2007, 32). Paraphrasing circumlocution would be a way of obviating the danger of linguistic usurpation that is patently triggered by the use of Shakespeare. By contrast, at roughly the same period of Perdita's childhood, Stella is also receptive, albeit with more distance, to the sonorities of the Indigenous language, to

the circulation of soft voices in a language she did not understand. [...] she thought it sounded Shakespearean, so full was it of convolution, evocation and rhyme. [...] what she heard were connections and collusions affirmed: a bracelet of propositions, perhaps, or an extra logic of meanings, from which she [Stella] was excluded. In words - she knew it - there were these revealed affiliations, these sensible families. (Jones 2007, 26)

It is symptomatic of the subsequent withdrawal of absolution that Stella both glimpses a more capacious language than Shakespeare (the "whispery sibilance and the bewildering quality of words and ideas [Stella] did not yet understand" recited as a child [Jones 2007,8$]$ ), yet feels herself excluded from it - where her daughter does not. Her sense of exclusion may have to do with her attempt to assimilate Indigenous sonorities to Shakespeare, thereby positing a kinship which is usurpatory rather than cautiously communicative.

It is at this juncture, I propose, that Jones proposes the possibility of a non-usurping communion between the cultures. Nicholas's condemnation of ostensibly anachronistic Indigenous kinship systems reposes in part upon his interest in James Frazer's The Golden Bough (Jones 2007, 142), a text that posits a putatively inevitable progress from "primitive" "magic" via "religion" to "science," modes of thought all posited as fundamentally different to one another (Frazer 1957, II, 931-932). It is significant, however, that about the same time that Jones's fiction takes place, Wittgenstein was reading Frazer against the grain. (Frazer and Wittgenstein, like Jones's Nicholas before his departure to Australia, were based in Cambridge). Wittgenstein co-opts Frazer's reading of "similarity" as a paradigm of purportedly primitive knowledge (Frazer 1957, I, 14-15) and twists it in a direction which doubtless would have been inimical to the author. Wittgenstein notes the "similarity" ("Ähnlichkeit') of pre-modern magical practices (based precisely on "similarity") and modern scientific reasoning (Wittgenstein 1989, 40-41) - a train of thought that will lead to his later meditations on "family resemblances" ('Familienähnlichkeiten,' Wittgenstein 1990, 138-140). Against Nicholas's rejection of kinship, Wittgenstein seems to be discovering the very sorts of "elective affinities" and open-familystructures that characterize adaptive, accommodative Indigenous knowledge systems (Muecke 2004; Rose 1996, 40-42) and to which Jones's text gives such 
prominence when it evokes "these revealed affiliations, these sensible families” (Jones 2007, 26).

This alternative mode of "kinship" may allow us, then, to envisage a mobilization of Shakespeare in the text that is not usurpatory. For, it is Shakespeare's sonnets that help Perdita to overcome her trauma-induced stutter, and it is the 'Give me the daggers' passage which restores her memory of her own act (Jones 2007, 191-197), the knowledge of Mary’s self-sacrifice, the prospect of an apology to her (though this chance is missed), and thus the knowledge of her own complicity in White usurpation. Shakespeare triggers a limited transformation, and - no less importantly - effects a knowledge of the limits of that transformation by virtue of a contextualization which is both connective and delimiting.

But there is more: when Perdita tells Mary the story of her name, paraphrasing The Winter's Tale, Mary responds both with narrative empathy but also with a counter-narrative of her own:

Mary also liked the story, particularly the part about the statue coming to life. [...] In blackfella stories, Mary said, things changed all the time: a tree into a woman, a woman into a tree. There were rocks that had been children and stars that talked. Spirit was everywhere, she insisted [...]. (Jones 2007, 64)

Shakespeare appears to be taken up within this process of transformative transmutation:

Mary had a theory that when people read the same words, they were imperceptibly knitted; that there were touchings not of the skin, and apparitional convergences. Some kind of spirit inhered in words that one might enter and engage with; [...] Mary extended to the written word the forms of community [...] just as, in their generosity, the creek people had bestowed on Perdita a relationship of skin. [...] A kind of family without limits. Occult relations. (Jones 2007, 73)

Shakespeare, recontextualized in Outback Australia and among the Nyoongar of urban Perth, assimilated into an Indigenous kinship system, appears thus not merely as a universalist usurper of other stories, but as a co-combatant in possible coalitions in the ongoing struggle against multiple colonial and neo-colonial usurpations. What Shakespeare appears to be telling us here, in his Antipodean, late modern, post-colonial avatar, would be that a literary work only ever has agency and validity in the contingent, constrained, collaborative, and often indirect relationships into which it enters via the mediating intervention of cultural workers, be they activist-writers, -readers, -critics, -teachers, or -students of literary texts. 


\section{Works Cited}

Agamben, Giorgio (1998). Homo Sacer: Sovereign Power and Bare Life. Trans. Daniel HellerRoazen. Stanford, CA: Stanford University Press.

Agamben, Giorgio (2005). State of Exception. Trans. Kevin Attell. Chicago, IL: University of Chicago Press.

ATSIC [Office of the Aboriginal and Torres Strait Islanders Justice Commissioner] (1996). Indigenous Deaths in Custody 1989-1996: A Report prepared by the Office of the Aboriginal and Torres Strait Islander Social Justice Commissioner for the Aboriginal and Torres Strait Islander Commission. Canberra: OATSIJC.

Bakhtin, Mikhail M. (1981). The Dialogic Imagination: Four Essays. Ed. Michael Holquist. Trans. Caryl Emerson and Michael Holquist. Austin, TX: University of Texas Press.

Banham, Martin, James Gibbs and Femi Osofisan, eds. (2013). African Theatre 12: Shakespeare in and out of Africa. Oxford: James Currey/Boydell and Brewer.

Barta, Tony (2008). "Sorry, and Not Sorry, in Australia: How the Apology to the Stolen Generations Buried a History of Genocide.” Journal of Genocide Research 10.2, 201-214.

Benjamin, Walter (1999). Illuminations. Trans. Harry Zohn. London: Pimlico.

Benterrak, Krim, Stephen Muecke and Paddy Roe (1984). Reading the Country: Introduction to Nomadology. Fremantle: Fremantle Arts Centre Press.

Berndt, Ronald M. and Catherine H. Berndt (1989). The Speaking Land: Myth and Story in Aboriginal Australia. Ringwood: Penguin.

Bonyhandy, Tim and Tom Griffiths, eds. (2002). Words for Country: Landscape and Language in Australia. Sydney: University of New South Wales Press.

Brantlinger, Patrick (1995). “Dying Races: Rationalising Genocide in the Nineteenth Century.” Jan Nederveen Pieterse and Bhikhu Parekh, eds. Decolonisation of the Imagination: Culture, Knowledge and Power. London: Zed, 43-55.

Brewster, Anne, Angeline O'Neill and Rosemary van den Berg, eds. (2000). Those Who Remain Will Always Remember: An Anthology of Aboriginal Writing. Fremantle: Fremantle Arts Centre Press.

Brooks, Cleanth (1947). The Well-Wrought Urn. New York, NY: Harcourt.

Coetzee, J.M. (2007). Diary of a Bad Year. London: Harvill Secker.

Coleridge, Samuel Taylor (1960). Shakespearean Criticism. Ed. Thomas Middleton Raysor. 2 vols. London: Dent.

Deleuze, Gilles (1988). Le Pli: Leibniz et le baroque. Paris: Minuit.

Distiller, Natasha (2005). South Africa, Shakespeare, and Post-Colonial Culture. Lewiston, NY: Edwin Mellon.

Eagleton, Terry (1967). Shakespeare and Society: Critical Studies in Shakespearean Drama. New York, NY: Schocken.

Foucault, Michel (2002). The Order of Things: An Archaeology of the Human Sciences. Trans. A.M. Sheridan Smith. London: Routledge.

Frazer, James G. (1957). The Golden Bough. Abridged ed. 2 vols. London: Macmillan.

Frow, John (2011). “A Politics of Stolen Time.” Jon May and Nigel Thrift, eds. TimeSpace: Geographies of Temporality. London: Routledge, 73-88.

Ghosh, Amitav (1994). In an Antique Land: History in the Guise of a Traveler's Tale. London: Granta/Penguin. 
Gray, Stephen (2011a). Brass Discs, Dog Tags and Finger Scanners: The Apology and Aboriginal Protection in the Northern Territory 1863-1972. Darwin: Charles Darwin University Press.

Gray, Stephen (2011b). The Protectors: A Journey Through Whitefella Past. Crows Nest, NSW: Allen and Unwin.

Haebich, Anna (2000). Broken Circles. Fragmenting Indigenous Families 1800-1990. Fremantle: Fremantle Arts Centre Press.

Haebich, Anna and Diane Mellor, eds. (2002). Many Voices: Reflections on Experiences of Indigenous Child Separation. Canberra: National Library of Australia.

Herrero, Dolores (2011). “The Australian Apology and Postcolonial Defamiliarization: Gail Jones’s Sorry.” Journal of Postcolonial Writing 47.3, 283-295.

HREOC [Human Rights and Equal Opportunities Commission Australia] (1997). Bringing Them Home: National Inquiry into the Separation of Aboriginal and Torres Strait Islanders from their Families. Sydney: HREOC.

Jones, Gail (2004). "Sorry-in-the-Sky: Empathetic Unsettlement, Mourning, and the Stolen Generations." Judith Ryan and Chris Wallace-Crabbe, eds. Imagining Australia: Literature and Culture in the New World. Cambridge, MA: Harvard University Press, 159-171.

Jones, Gail (2007). Sorry. London: Vintage.

Kantorowicz, Ernst H. (1957). The King's Two Bodies: A Study in Medieval Political Theology. Princeon, NJ: Princeton University Press.

Kiernan, Victor (1996). Eight Tragedies of Shakespeare: A Marxist Study. London: Verso.

Kirby, W.J.T. (1999). "Richard Hooker's Theory of Natural Law in the Context of Reformation Theology." Sixteenth Century Journal 30.3, 681-703.

Kossew, Sue (2013). "Saying Sorry: The Politics of Apology and Reconciliation in Recent Australian Novels." Walter Goebel and Saskia Schabio, eds. Locating Postcolonial Narrative Genres. London/New York, NY: Routledge, 171-183.

Loomba, Ania (1989). Gender, Race, Renaissance Drama. Manchester: Manchester University Press.

Lovejoy, Arthur O. (1957). The Great Chain of Being: A Study of the History of an Idea. Cambridge, MA: Harvard University Press.

Mamajun Torres, Patricia (2000). "Bilyurr-Bilyurr Jarndu: The Red-Dress Woman - A Yawuru Story." Anne Brewster, Angeline O'Neill and Rosemary van den Berg, eds. Those Who Remain Will Always Remember: An Anthology of Aboriginal Writing. Fremantle: Fremantle Arts Centre Press, 19-20.

Mbembe, Achille (2003). “Necropolitics.” Public Culture 15.1, 11-40.

Muecke, Stephen (2004). Ancient \& Modern: Time, Culture and Indigenous Philosophy. Sydney: University of New South Wales Press.

Orkin, Martin (1987). Shakespeare against Apartheid. Craighall Park: A. D. Donker.

Pilkington, Doris/Nugi Garimara (1996). Follow the Rabbit-Proof Fence. St Lucia: University of Queensland Press.

Reynolds, Henry (1996). Aboriginal Sovereignty: Three Nations, One Australia?. Sydney: Allen and Unwin.

Rickard, John (1996). Australia: A Cultural History. 2nd ed. London: Longman.

Roe, Paddy (1983). Gularabulu: Stories from the West Kimberley. Ed. Stephen Muecke. Fremantle: Fremantle Arts Centre Press.

Rose, Deborah Bird (1996). Nourishing Terrains: Australian Aboriginal Views of Landscape and Wilderness. Canberra: Australian Heritage Commission.

Rose, Deborah Bird (2004). Reports from a Wild Country: Ethics for Decolonisation. Sydney: University of New South Wales Press. 
Rowse, Tim (1993). After Mabo: Interpreting Indigenous Traditions. Carlton: Melbourne University Press.

Royal Commission into Aboriginal Deaths in Custody (1991). National Reports, 5 vols. Indigenous Law Recources - Reconciliation and Social Justice Library. <http://www.austlii.edu.au/au/ other/IndigLRes/rciadic/?utm_source=PoliticOz\&utm_campaign=4ca357a674PoliticOZ_26_ September_2014\&utm_medium=email\&utm_term=0_673b6b002d4ca357a674-302966797> (December 2, 2014).

Rudd, Kevin (2008). “Apology to Australia's Indigenous Peoples.” Australian Parliament, 13 February 2008. <http://www.australia.gov.au/about-australia/our-country/our-people/ apology-to-australias-indigenous-peoples> (November 29, 2014).

Schalkwyk, David (2012). Hamlet's Dream: The Robben Island Shakespeare. London: Bloomsbury.

Scott, Kim (1999). Benang: From the Heart. Fremantle: Fremantle Arts Centre Press.

Shakespeare, William (1988). The Complete Works: Compact Edition. Stanley Wells and Gary Taylor, eds. Oxford: Clarendon Press/Oxford University Press.

Spivak, Gayatri Chakravorty (1993). “An Interview with Gayatri Chakravorty Spivak.” Interview. By Sara Danius and Stefan Jonsson. Boundary 2: An International Journal of Literature and Culture 20.2 (Summer), 24-50.

Spivak, Gayatri Chakravorty (1999). A Critique of Postcolonial Reason: Towards a History of the Vanishing Present. Cambridge, MA: Harvard University Press.

Stanner, W.E.H. (1969). After the Dreaming: The 1968 Boyer Lectures. Sydney: Australian Broadcasting Commission.

Swain, Tony (1993). A Place for Strangers: Towards a History of Australian Aboriginal Being. Cambridge: Cambridge University Press.

Taylor, Gary (1991). Reinventing Shakespeare: A Cultural History from the Restoration to the Present. London: Vintage.

Tillyard, E.M.W. ([1943] 1978). The Elizabethan World Picture. Harmondsworth: Penguin/Chatto and Windus.

Vattimo, Gianni (1980). L'Avventure della differenza. Milan: Garzanti.

Viswanathan, Gauri (2015). Masks of Power: Literary Study and British Rule in India. New ed. New York, NY: Columbia University Press.

West-Pavlov, Russell (2013). Temporalities. London: Routledge.

Wittgenstein, Ludwig (1989). Vortrag über Ethik und andere kleine Schriften. Ed. Joachim Schulte. Frankfurt/Main: Suhrkamp.

Wittgenstein, Ludwig (1990). Tractatus Logico-philosophicus / Philosophische Untersuchungen. Leipzig: Reclam. 